\title{
Treatment with novel AP-1 and NF-кB inhibitors restores the colonic endocrine cells to normal levels in rats with DSS-induced colitis
}

\author{
MAGDY EL-SALHY ${ }^{1-3}$ and KAZUO UMEZAWA ${ }^{4}$ \\ ${ }^{1}$ Division of Gastroenterology, Department of Medicine, Stord Helse-Fonna Hospital, Stord; ${ }^{2}$ Division of Gastroenterology, \\ Institute of Clinical Medicine, University of Bergen; ${ }^{3}$ National Centre for Functional Gastrointestinal Disorders, \\ Department of Medicine, Haukeland University Hospital, Bergen, Norway; ${ }^{4}$ Department of Molecular Target Medicine, \\ School of Aichi Medical University, School of Medicine, Nagakute, Aichi, Japan
}

Received November 6, 2015; Accepted January 27, 2016

DOI: $10.3892 / \mathrm{ijmm} .2016 .2481$

\begin{abstract}
The aim of this study was to determine the effects of two anti-inflammatory agents on the abnormalities in colonic endocrine cells in dextran sodium sulfate (DSS)-induced colitis. Colitis was induced in male Wistar rats $(n=45)$ using DSS; a further 15 rats without colitis were included in a healthy control group. The animals with DSS-induced colitis were randomly divided into 3 treatment groups as follows: i) DSS group, rats were treated with $0.5 \mathrm{ml}$ of $0.5 \%$ carboxymethyl cellulose (CMC); ii) DSS-G group, rats were treated with 3-[(dodecyl thiocarbonyl)-methyl]-glutarimide (DTCM-G), a novel activator protein 1 (AP-1) inhibitor, $20 \mathrm{mg} / \mathrm{kg}$ in CMC; and iii) DSS-Q group, rats were treated with dehydroxymethylepoxyquinomicin, a nuclear factor $\kappa \mathrm{B}(\mathrm{NF}-\kappa \mathrm{B})$ inhibitor, $15 \mathrm{mg} / \mathrm{kg}$ in $\mathrm{CMC}$. The treatments were administered intraperitoneally, twice daily for 5 days, after which the animals were sacrificed and tissue samples from the colon were immunostained for chromogranin A (CgA), serotonin, peptide YY (PYY), enteroglucagon, pancreatic polypeptide (PP), somatostatin, leukocytes, B/T lymphocytes, B lymphocytes, T lymphocytes, macrophages/monocytes and mast cells. The densities of these endocrine and immune cells were quantified by computer-aided image analysis. The densities of CgA-, serotonin-, PYY- and enteroglucagon-producing cells were significantly higher, and those of PP- and somatostatin-producing cells were significantly lower in the DSS-G, DSS-Q and control groups than in the DSS group. The densities of all the immune cells were lower in the DSS-G, DSS-Q and control groups than in the DSS group. The densities of all endocrine cell types and immune cells in both the DSS groups treated with anti-inflammatory agents were
\end{abstract}

Correspondence to: Professor Magdy El-Salhy, Division of Gastroenterology, Department of Medicine, Stord Helse-Fonna Hospital, Tysevegen 64, 5416 Stord, Norway

E-mail: magdy.el-salhy@helse-fonna.no

Key words: chromogranin A, dextran sodium sulfate-induced colitis, peptide YY, somatostatin, serotonin restored to control levels. In conclusion, our data demonstrate that there is an interaction between endocrine and immune cells during inflammation. This interaction with subsequent changes in endocrine cells is responsible for the clinical manifestation of colitis symptoms.

\section{Introduction}

The intestinal endocrine cells have been reported to be abnormal in patients with inflammatory bowel disease (IBD) and in animal models of IBD (1-20). Recent discussion on the interaction between the hormones secreted by gut endocrine cells and the immune system has led to the hypothesis that this interaction plays an important role in the pathophysiology of IBD $(21,22$, unpublished data). One recent study found that the densities of all colonic endocrine cell types were affected in rats with dextran sodium sulfate (DSS)-induced colitis, and that this change strongly correlated with changes in the densities of mucosal immune cells caused by the inflammation (unpublished data). These findings confirmed the likelihood of an interaction between intestinal hormones and the immune cells.

3-[(Dodecylthiocarbonyl)-methyl]-glutarimide (DTCM-G) is a synthetic derivative of 9-methylstreptimidone, which is a potent anti-inflammatory agent that suppresses activator protein 1 (AP-1), and dehydroxymethylepoxyquinomicin (DHME-Q) is a low-molecular-weight nuclear factor $\kappa \mathrm{B}(\mathrm{NF}-\kappa \mathrm{B})$ inhibitor that also exhibits potent anti-inflammatory activity. Both of these anti-inflammatory agents have been shown to be effective in animal models of IBD (23-26). The aim of this study was to determine whether the anti-inflammatory effects of these two agents restore the densities of colonic endocrine cells to normal levels in rats with DSS-induced colitis.

\section{Materials and methods}

Rats. Sixty male Wistar rats (Hannover GALAS; Taconic Farms, Inc., Lille Skensved, Denmark) with a mean body weight of $290 \mathrm{~g}$ (range, 241-395 g) were housed in Makrolon III cages with ad libitum access to water and food. They were fed a standard diet (B\&K Universal AS, Nittedal, Norway) and 
Table I. Summary of the primary antibodies used in this study.

\begin{tabular}{|c|c|c|c|c|}
\hline Antibodies raised against & Type of antibody & Source & Code no. & Detects \\
\hline $\mathrm{N}$-terminal of purified $\mathrm{CgA}$ & $\begin{array}{l}\text { Monoclonal, } \\
\text { raised in mouse }\end{array}$ & $\begin{array}{l}\text { Dako, Glostrup, } \\
\text { Denmark }\end{array}$ & M869 & $\mathrm{CgA}$ \\
\hline Serotonin & $\begin{array}{l}\text { Monoclonal, } \\
\text { raised in mouse }\end{array}$ & $\begin{array}{l}\text { Dako, Glostrup, } \\
\text { Denmark }\end{array}$ & 5НТ-209 & Serotonin \\
\hline PYY & $\begin{array}{l}\text { Polyclonal, } \\
\text { raised in rabbit }\end{array}$ & $\begin{array}{l}\text { Alpha-Diagnostica, } \\
\text { San Antonio, TX, USA }\end{array}$ & PYY 11A & PYY \\
\hline Porcine glicentin/glucagon & $\begin{array}{l}\text { Polyclonal, } \\
\text { raised in rabbit }\end{array}$ & $\begin{array}{l}\text { Acris Antibodies, } \\
\text { Herford, Germany }\end{array}$ & BP508 & $\begin{array}{l}\text { Enteroglucagon } \\
\text { (oxyntomodulin) }\end{array}$ \\
\hline Synthetic human PP & $\begin{array}{l}\text { Polyclonal, } \\
\text { raised in rabbit }\end{array}$ & $\begin{array}{l}\text { Diagnostic Biosystems, } \\
\text { Pleasanton, CA, USA }\end{array}$ & \#114 & $\mathrm{PP}$ \\
\hline $\begin{array}{l}\text { Synthetic human } \\
\text { somatostatin }\end{array}$ & $\begin{array}{l}\text { Polyclonal, } \\
\text { raised in rabbit }\end{array}$ & $\begin{array}{l}\text { Dako, Glostrup, } \\
\text { Denmark }\end{array}$ & A566 & Somatostatin \\
\hline Human CD45 & $\begin{array}{l}\text { Monoclonal, } \\
\text { raised in mouse }\end{array}$ & $\begin{array}{l}\text { Dako, Glostrup, } \\
\text { Denmark }\end{array}$ & M0701 & $\begin{array}{l}\text { CD45 is considered a } \\
\text { common leukocyte antigen } \\
\text { and is expressed exclusively } \\
\text { on cells of the hematopoietic } \\
\text { system and their progenitors }\end{array}$ \\
\hline Human CD5 & $\begin{array}{l}\text { Monoclonal, } \\
\text { raised in mouse }\end{array}$ & $\begin{array}{l}\text { Dako, Glostrup, } \\
\text { Denmark }\end{array}$ & IS082 & B and T lymphocytes \\
\hline Human CD57 & $\begin{array}{l}\text { Monoclonal, } \\
\text { raised in mouse }\end{array}$ & $\begin{array}{l}\text { Dako, Glostrup, } \\
\text { Denmark }\end{array}$ & IS647 & $\begin{array}{l}\text { Subsets of natural killer of } \\
\text { cells and } \mathrm{CD} 8^{+} \text {lymphocytes, } \\
\text { and by a small proportion } \\
\mathrm{CD} 4^{+} / \mathrm{CD} 45 \mathrm{R}^{+} \\
\text {T lymphocytes }\end{array}$ \\
\hline Human CD23 & $\begin{array}{l}\text { Monoclonal, } \\
\text { raised in mouse }\end{array}$ & $\begin{array}{l}\text { Dako, Glostrup, } \\
\text { Denmark }\end{array}$ & IS781 & B lymphocytes \\
\hline Human CD68 & $\begin{array}{l}\text { Monoclonal, } \\
\text { raised in mouse }\end{array}$ & $\begin{array}{l}\text { Dako, Glostrup, } \\
\text { Denmark }\end{array}$ & M0814 & $\begin{array}{l}\text { Monocytes, macrophages, } \\
\text { and myeloid cells }\end{array}$ \\
\hline Human mast cell tryptase & $\begin{array}{l}\text { Monoclonal, } \\
\text { raised in mouse }\end{array}$ & $\begin{array}{l}\text { Dako, Glostrup, } \\
\text { Denmark }\end{array}$ & M7052 & Mast cells \\
\hline
\end{tabular}

CgA, chromogranin A; PYY, peptide YY; PP, pancreatic polypeptide.

maintained in an environment at $21 \pm 1^{\circ} \mathrm{C}$, a relative humidity of $55 \pm 5 \%$ and a 12/12 $\mathrm{h}$ light/dark cycle. The animals were allowed to acclimatize in the animal house for 8 days prior to the experiments, and were then divided into 4 groups of 15 animals each.

The animals in the control group were provided with normal drinking water for 7 days, and colitis was induced in the rats in the remaining 3 groups by providing the rats with distilled water containing 5\% DSS (molecular weight $40 \mathrm{kDa}$; TdB Consultancy, Uppsala, Sweden), which was prepared daily, for 7 days, as previously described $(27,28)$. The 3 DSS-treated groups were then randomized to receive the vehicle $[0.5 \mathrm{ml}$ of $0.5 \%$ carboxymethyl cellulose (CMC; DSS group)], DTCM-G at $20 \mathrm{mg} / \mathrm{kg}$ body weight in $0.5 \% \mathrm{CMC}$ (DSS-G group), and DHME-Q at $15 \mathrm{mg} / \mathrm{kg}$ body weight in $0.5 \%$ CMC (DSS-Q group), intraperitoneally, twice daily for 5 days. The synthesis of DTCM-G and DHME-Q is described elsewhere (23,27-31). The animals were monitored twice daily, and any animals exhibiting signs of pain were administered a subcutaneous injection of $1 \mathrm{ml}$ of Temgesic solution (containing $0.3 \mathrm{~g} / \mathrm{ml}$ Temgesic; Merck Pharmaceutical).
At the end of the 5-day treatment period, all the animals were sacrificed by $\mathrm{CO}_{2}$ inhalation, and a post-mortem laparotomies were carried out. The colon was dissected out, and tissue samples were taken from the lower part of the colon for histological examinations.

The local ethics committee for the Protection of Vertebrate Animals used for Experimental and Other Scientific Purposes approved the study protocols.

Histopathology and immunohistochemistry. The tissue samples were fixed overnight in $4 \%$ buffered paraformaldehyde, embedded in paraffin and then sectioned at a thickness of $5 \mu \mathrm{m}$. The sections were deparaffinized and then stained with hematoxylin and eosin, or immunostained using the ultraView Universal DAB Detection kit (version 1.02.0018) and the BenchMark Ultra IHC/ISH staining module (both from Ventana Medical Systems, Basel, Switzerland). The sections were immunostained by incubating them with one of the primary antibodies for $32 \mathrm{~min}$ at $37^{\circ} \mathrm{C}$. The primary antibodies used are summarized in Table I. 

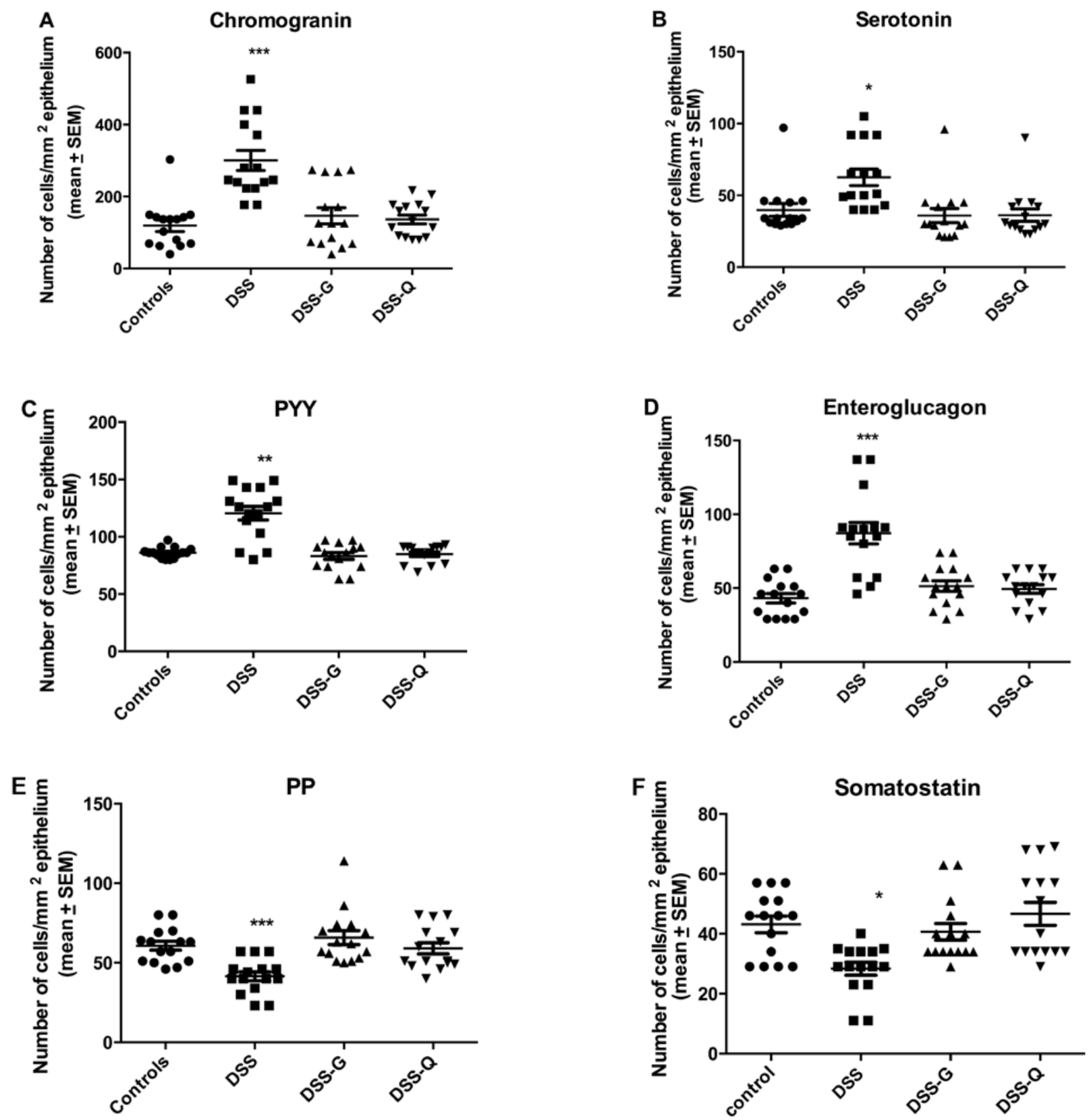

Figure 1. Densities of different colonic endocrine cells in control rats and in rats with dextran-sulfate-sodium-induced colitis (DSS), rats with DSS-induced colitis and treated with DTCM-G (DSS-G), and rats with DSS-induced colitis and treated with DHME-Q (DSS-Q). ${ }^{* * * *} \mathrm{P}<0.0001,{ }^{* * *} \mathrm{P}<0.01,{ }^{*} \mathrm{P}<0.05$ vs. controls.

Quantification of endocrine and immune cells. The endocrine and immune cells were quantified using Olympus cellSens imaging software (version 1.7) as described elsewhere $(32,33)$. A $x 40$ objective was used, which meant that each frame (field) displayed on the monitor represented a tissue area of $0.035 \mathrm{~mm}^{2}$. The data are presented as the number of cells $/ \mathrm{mm}^{2}$ of epithelium for endocrine cells, and the number of cells per field for immune cells. The sections were coded, and the measurements were made by the same person (M.E.-S.) who was unaware of the identity of the sections.

Statistical analysis. The Kruskal-Wallis non-parametric test, with Dunn's test as a post-test was used to compare the findings obtained form the animals in the control, DSS, DSS-G and DSS-Q groups. The data are presented as the mean \pm SEM values, and the cut-off for statistical significance was set at $\mathrm{P}<0.05$.

\section{Results}

The examination of the hematoxylin and eosin-stained sections of the colonic tissues revealed normal histological results in the control, DSS-G, and DSS-Q groups, while a disrupted mucosal architecture, edema, bleeding, crypt abscesses and immune cell infiltration into the mucosa and submucosa were observed in the DSS group.

Endocrine cells. The cell densities of various endocrine cell types in the control, DSS, DSS-G, and DSS-Q groups are summarized in Table II and illustrated in Figs. 1-3. 
Table II. Densities of the different endocrine cell types (number $/ \mathrm{mm}^{2}$ of epithelium) in the control animals, and in animals with DSS-induced colitis treated with the vehicle (CgA, DSS group), DTCM-G (DSS-G group) and DHME-Q (DSS-Q group).

\begin{tabular}{lcccccc}
\hline & \multicolumn{5}{c}{ Endocrine cell type } \\
\cline { 2 - 7 } Animal group & CgA & Serotonin & PYY & Enteroglucagon & PP & Somatostatin \\
\hline Control & $119.0 \pm 16.5$ & $39.9 \pm 4.4$ & $96.0 \pm 1.2$ & $43.1 \pm 3.2$ & $60.7 \pm 2.8$ & $43.1 \pm 2.8$ \\
DSS & $300.6 \pm 27.7^{\mathrm{a}}$ & $62.6 \pm 5.8^{\mathrm{a}}$ & $120.5 \pm 5.9^{\mathrm{b}}$ & $87.2 \pm 7.2^{\mathrm{a}}$ & $41.5 \pm 2.8^{\mathrm{a}}$ & $28.3 \pm 2.2^{\mathrm{c}}$ \\
DSS-G & $146.7 \pm 22.4$ & $35.9 \pm 4.9$ & $98.2 \pm 7.0$ & $51.3 \pm 3.6$ & $65.8 \pm 4.4$ & $40.7 \pm 2.7$ \\
DSS-Q & $136.6 \pm 12.2$ & $36.2 \pm 4.3$ & $84.8 \pm 2.0$ & $49.5 \pm 2.9$ & $59.1 \pm 3.5$ & $46.7 \pm 3.8$ \\
\hline
\end{tabular}

Data are the mean \pm SEM values DSS, dextran sodium sulfate; DTCM-G, 3-[(dodecylthiocarbonyl)-methyl]-glutarimide; DHME-Q, dehydroxymethylepoxyquinomicin; CgA, chromogranin A; PYY, peptide YY; PP, pancreatic polypeptide. ${ }^{\mathrm{a} P}<0.0001,{ }^{\mathrm{b}} \mathrm{P}<0.01$ and ${ }^{\mathrm{C}} \mathrm{P}<0.05$ vs. controls.
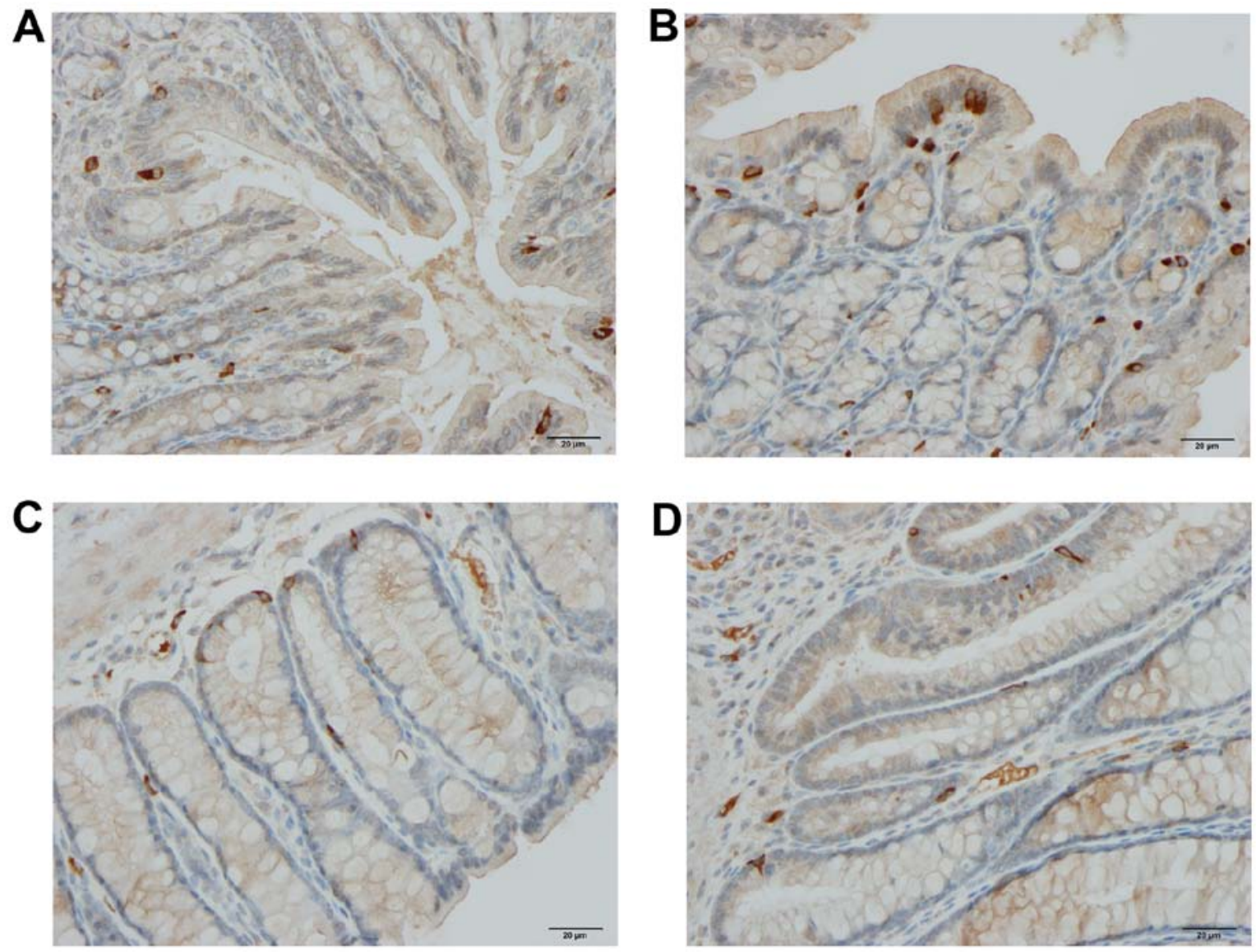

Figure 2. Chromogranin A-producing cells in the colons of rats from the control (A), DSS (B), DSS-G (C) and DSS-Q (D) groups.

Chromogranin A (CgA)-producing cells. The density CgA-producing cells was significantly higher in the DSS group than in the control, DSS-G, and DSS-Q groups $(\mathrm{P}<0.0001$, 0.0009 and $<0.0001$, respectively). There was no significant difference observed between the control group and the DSS-G and DSS-Q groups ( $\mathrm{P}=0.6$ and 0.2 , respectively).

Serotonin-producing cells. The density serotonin-producing cells was significantly higher in the DSS group than in the control, DSS-G and DSS-Q groups $(\mathrm{P}=0.0006,0.0006$ and 0.0003 , respectively), and it did not differ significantly between the control group and the DSS-G and DSS-Q groups $(\mathrm{P}=0.1$ for both).

Peptide YY (PYY)- and enteroglucagon-producing cells. The densities of the PYY- and enteroglucagon- producing cells were significantly higher in the DSS group than in the control, DSS-G and DSS-Q groups (PYY, $\mathrm{P}=0.005,0.04$ and 0.005, respectively; and enteroglucagon, $\mathrm{P}<0.0001,0.0004$ and 0.0004, respectively). The cell density did not differ significantly between the control group and the DSS-G and DSS-Q groups for either PYY $(\mathrm{P}=0.2$ and 0.9$)$ or enteroglucagon ( $\mathrm{P}=0.1$ for both). 

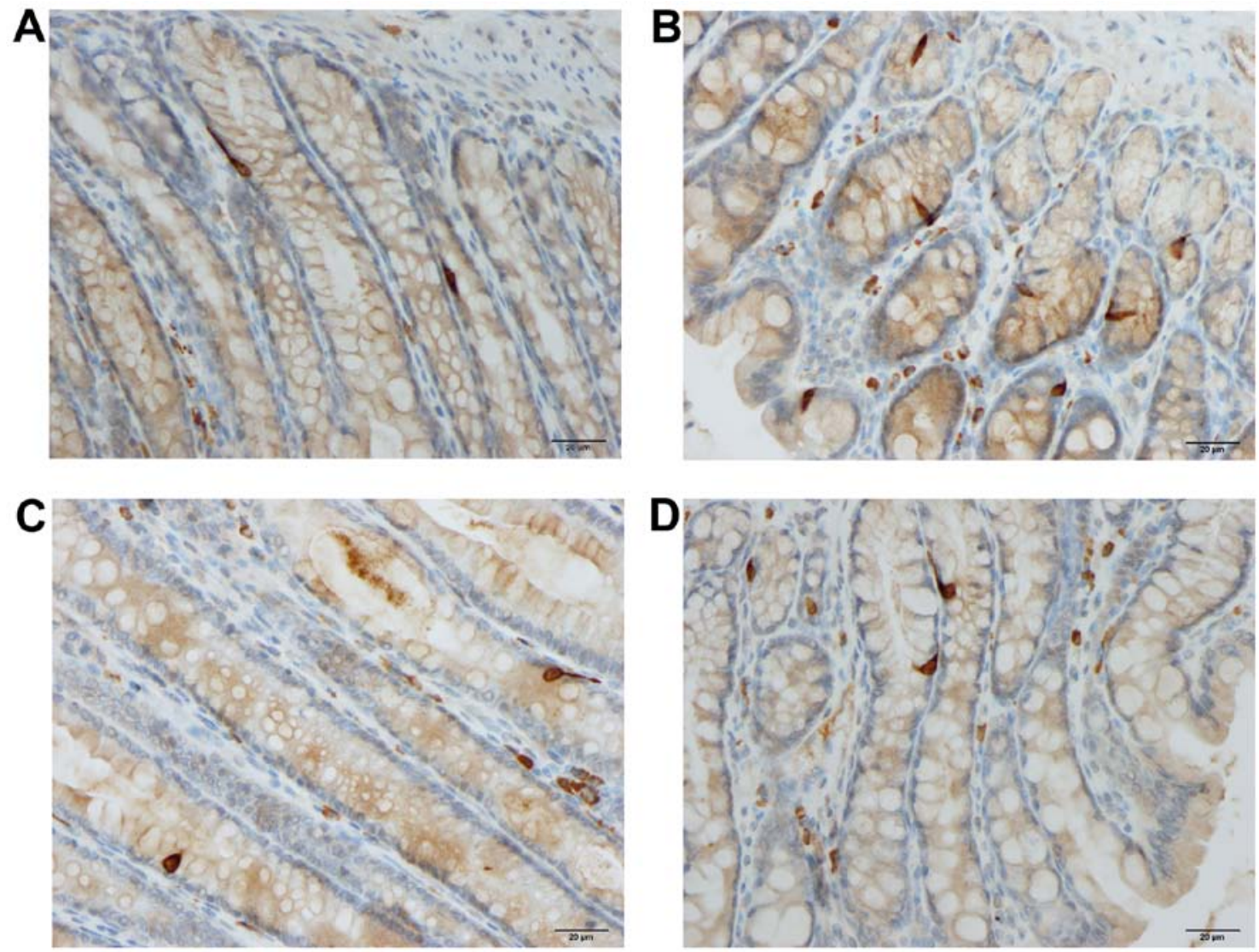

Figure 3. Colonic peptide YY-producing cells in rats from the control (A), DSS (B), DSS-G (C), and DSS-Q (D) groups.

Table III. Densities of the various immune cells (number/field) in the control group and various experimental treatment groups with DSS-induced colitis.

\begin{tabular}{lcccccr}
\hline & \multicolumn{5}{c}{ Immune cell type } \\
\cline { 2 - 6 } Animal group & Leukocytes & B/T lymphocytes & B lymphocytes & T lymphocytes & Macrophages/monocytes & Mast cells \\
\hline Control & $5.9 \pm 0.3$ & $7.6 \pm 0.7$ & $9.5 \pm 0.5$ & $5.9 \pm 0.5$ & $6.9 \pm 0.3$ & $5.5 \pm 0.5$ \\
DSS & $22.4 \pm 1.9^{\mathrm{a}}$ & $23.5 \pm 1.4^{\mathrm{a}}$ & $23.7 \pm 1.9^{\mathrm{a}}$ & $26.2 \pm 2.6^{\mathrm{a}}$ & $22.1 \pm 1.8^{\mathrm{a}}$ & $27.7 \pm 1.9^{\mathrm{a}}$ \\
DSS-G & $6.8 \pm 0.8$ & $7.6 \pm 0.6$ & $8.8 \pm 0.7$ & $7.6 \pm 0.9$ & $6.9 \pm 0.5$ & $7.1 \pm 0.8$ \\
DSS-Q & $5.8 \pm 0.6$ & $7.3 \pm 0.6$ & $8.7 \pm 0.6$ & $7.7 \pm 0.6$ & $6.4 \pm 0.7$ & $6.5 \pm 0.7$ \\
\hline
\end{tabular}

Data are the mean \pm SEM values DSS, dextran sodium sulfate. ${ }^{\mathrm{a}} \mathrm{P}<0.0001$ vs. controls.

Pancreatic polypeptide (PP)- and somatostatin-producing cells. Both the densities of PP- and somatostatin-producing cells were significantly lower in the DSS group than in the control, DSS-G, and DSS-Q groups (PP, P=0.0001, <0.0001 and 0.0008, respectively; and somatostatin, $0.02,0.003$ and 0.001 , respectively). The cell density did not differ significantly between the control group and the DSS-G and DSS-Q groups for either PP $(\mathrm{P}=0.5$ and 0.6 , respectively) or somatostatin $(\mathrm{P}=0.6$ and 0.5 , respectively).

Immune cells. The densities of the immune cells in the control, DSS, DSS-G, and DSS-Q groups are presented in Table III and Figs. 4-6.
Leukocytes. The density of leukocytes was significantly higher in the DSS group than in the control, DSS-G, and DSS-Q groups $(\mathrm{P}<0.0001$ for all), and it did not differ significantly between the control group and the DSS-G and DSS-Q groups $(\mathrm{P}=0.3$ and 0.9 , respectively).

Lymphocytes. The density of B/T lymphocytes (Fig. 5) in the DSS group was increased relative to the control, DSS-G, and DSS-Q groups $(\mathrm{P}<0.0001$ for all $)$, as were the densities of the $\mathrm{B}$ lymphocytes $(\mathrm{P}<0.0001$ for all) and $\mathrm{T}$ lymphocytes $(\mathrm{P}<0.0001$ for all). There were no differences observed between the control group and the DSS-G and DSS-Q groups with respect to the densities of B/T lympho- 
A

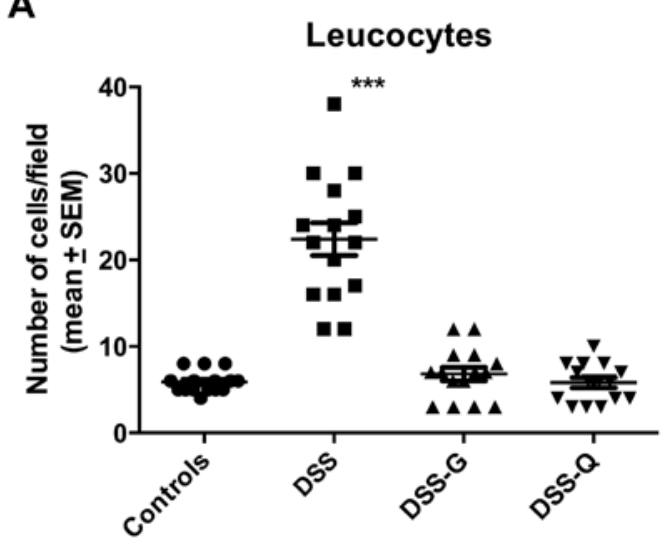

C

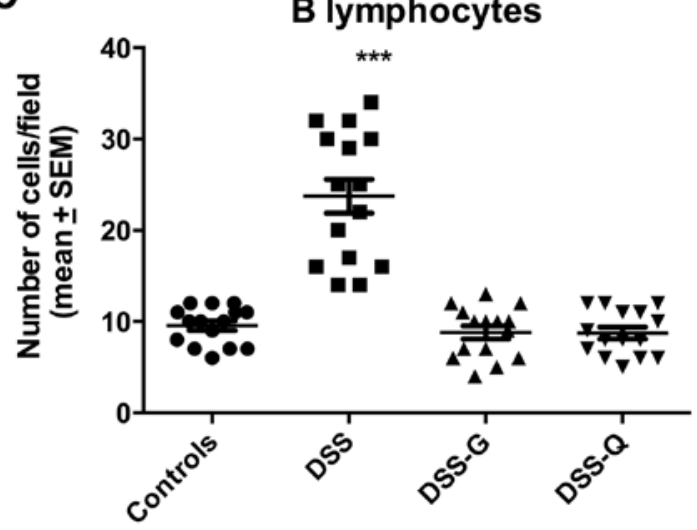

E

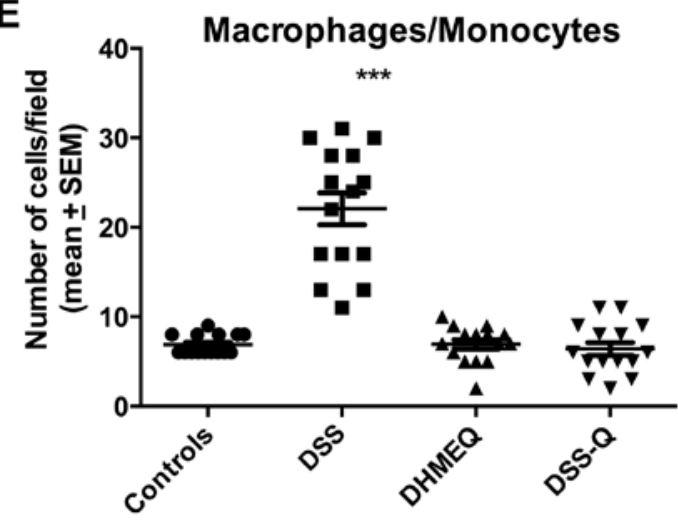

B

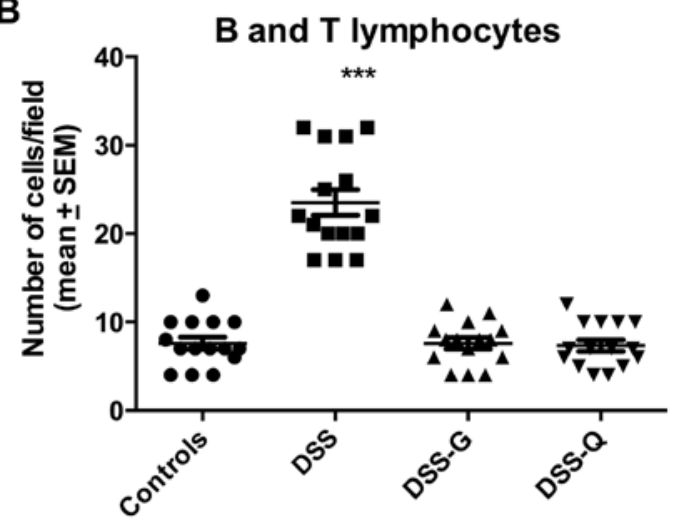

D

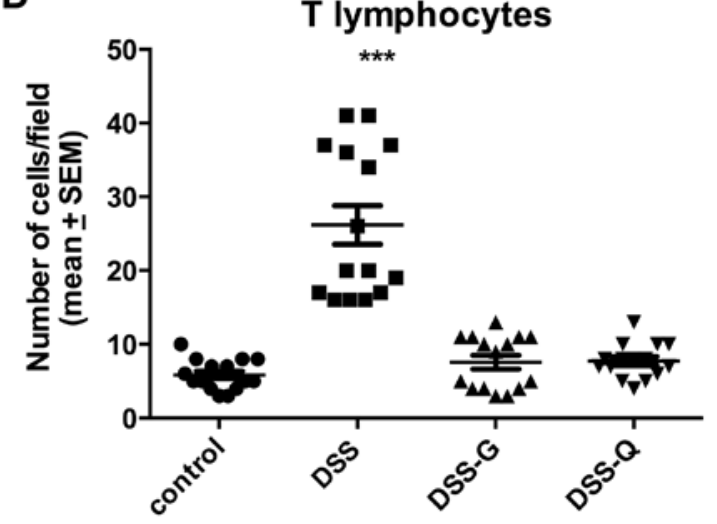

$\mathbf{F}$

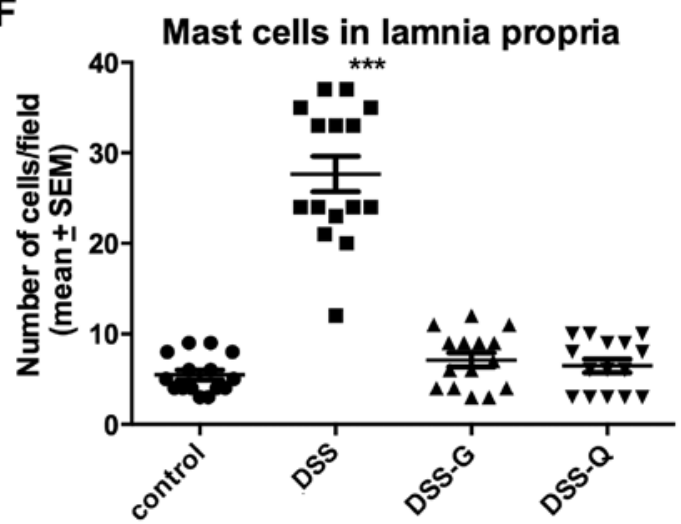

Figure 4. Densities of various immune cells in the colonic lamina propria of control, DSS, DSS-G and DSS-Q group rats. ${ }^{* * * *} \mathrm{P}<0.0001,{ }^{* * *} \mathrm{P}<0.01,{ }^{*} \mathrm{P}<0.05$ vs. controls.

cytes $(\mathrm{P}=0.9$ and 0.7 , respectively), B lymphocytes $(\mathrm{P}=0.9$ and 0.7 , respectively) and $\mathrm{T}$ lymphocytes $(\mathrm{P}=0.2$, and 0.2 , respectively).

Macrophages/monocytes. The density of macrophages/monocytes was higher in the DSS group than in the control, DSS-G, and DSS-Q groups $(\mathrm{P}<0.0001$ for all), and did not differ significantly between the control group and the DSS-G and DSS-Q groups ( $\mathrm{P}=0.7$ and 0.4 , respectively).

Mast cells. The density of mast cells (Fig. 6) was significantly higher in the DSS group than in the control, DSS-G, and DSS-Q groups $(\mathrm{P}<0.0001$ for all), and did not differ signifi- cantly between the control group and the DSS-G and DSS-Q groups $(\mathrm{P}=0.2$ and 0.4 , respectively).

\section{Discussion}

DSS-induced colitis is an animal model that closely replicates both the clinical and morphological characteristics of human ulcerative colitis (UC) (34). Thus, animals with DSS-induced colitis suffer from bloody diarrhea, dehydration and the loss of body weight (34). Furthermore, the morphological features resemble human UC both macroscopically and microscopically (35). However, this model lacks the chronicity (i.e., disease relapse and remission) observed in 

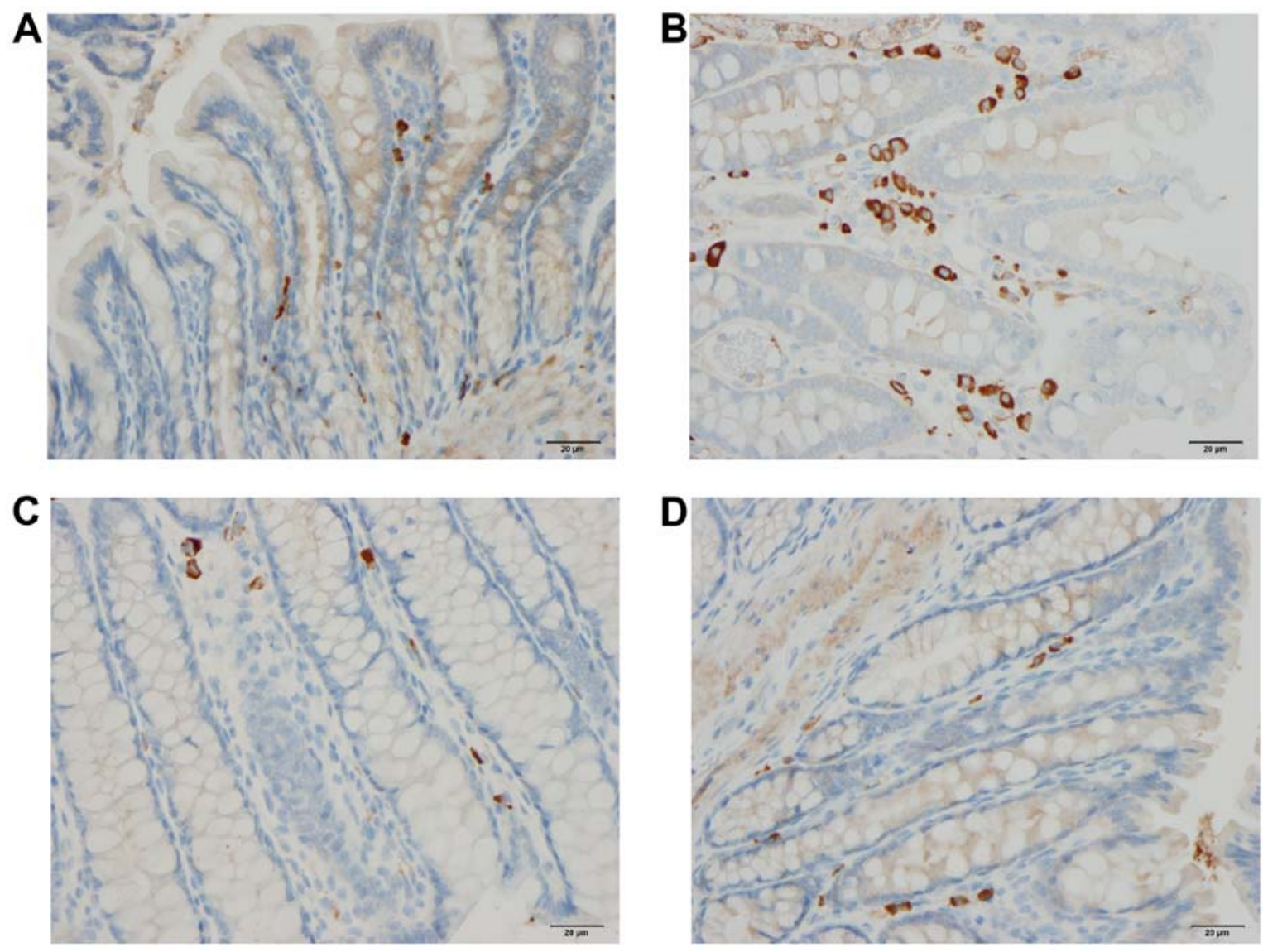

Figure 5. B/T lymphocytes in rats from the control (A), DSS (B), DSS-G (C) and DSS-Q (D) groups.
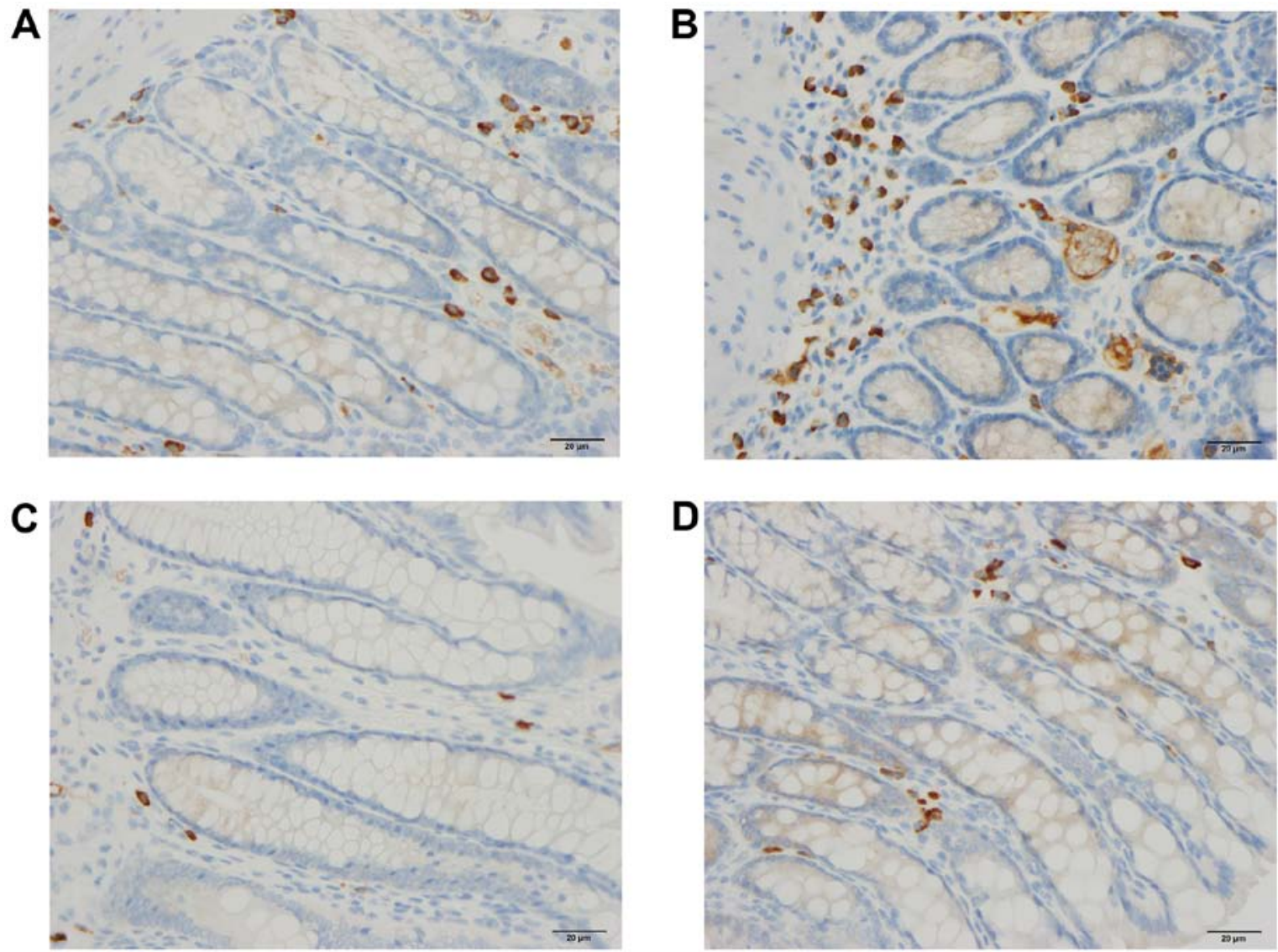

Figure 6. Mast cells in rats from the control (A), DSS (B), DSS-G (C) and DSS-Q (D) groups. 
human UC (35). Therefore, care should be taken when drawing conclusions about human UC based on this model.

In the present study, 5 days of treatment with either DTCM-G or DHME-Q ameliorated the inflammation caused by DSS, as indicated by the restored mucosal architecture and normal histological appearance in the animals with DSS-induced colitis treated with these agents compared to the untreated controls with DSS-induced colitis. This finding is in line with the results of previously published studies on colitis induced by trinitrobenzene sulfonic acid (TNBS) and DSS in rats and mice (25,26, unpublished data). This resolution of inflammation was associated with the restoration of the normal densities of all colonic endocrine cell types to normal levels. DTCM-G and DHME-Q are anti-inflammatory agents with different modes of action: the former acts by inhibiting AP-1, while the latter inhibits $\mathrm{NF}-\kappa \mathrm{B}$. Thus, the effects of these substances on colonic endocrine cell densities cannot be attributed to a direct effect on the endocrine cells; rather, they are more likely to be attributable to their effects on inflammation.

There is a growing body of evidence indicating that some of the hormones produced by the colonic endocrine cells investigated herein interact with the immune cells during the inflammation process. Thus, $\mathrm{CgA}$ peptides reduce the release of interleukin (IL)-16 and IL-5, with the reduction of the number of lymphocytes at the sites inflammation and hence the proinflammatory action of lymphocytes and monocytes (36-38). Moreover, $\mathrm{CgA}$ inhibits the vascular leakage caused by tumor necrosis factor $\alpha$ (TNF- $\alpha$ ) (39). The serotonin cell number has been reported to be reduced in mice lacking the $\mathrm{T}$ lymphocyte receptors (36), IL-13 receptors have been shown to be localized on serotonin-producing cells (40) and serotonin receptors have been found in lymphocytes, monocytes, machrophages and dendritic cells (41). Furthermore, serotonin the inhibits apoptosis of immune cells and promotes the recruitment of $\mathrm{T}$ cells, and affects the proliferation of lymphocytes, protects natural killer cells (42-45). The present observation that the immune cell densities were normalized to the same extent as the colonic endocrine cells following treatment with DTCM-G and DHME-Q, and the previous finding of a strong correlation between the changes in immune cells and endocrine cells in rats with DSS-induced colitis support the suggested interaction between the two types of cell during the inflammatory process (unpublished data).

It has been proposed that changes in the endocrine cell density in response to or as a result of inflammation play a major role in the manifestation of clinical symptoms such as accelerated intestinal motility, decreased intestinal absorption of water and electrolytes, and diarrhea (unpublished data). Treatment with either DTCM-G or DHME-Q, administered under the same regimen as that used in the present study, was also found to improve these clinical symptoms in DSS-induced colitis in rats (unpublished data). The present finding that treatment with these anti-inflammatory agents restores the densities of the endocrine cells supports the assumption regarding the importance of changes in the endocrine cell populations in the development of the clinical symptoms during colitis.

\section{Acknowledgements}

The present study was supported by grants from Helse-Vest and Helse-Fonna.

\section{References}

1. El-Salhy M, Danielsson A, Stenling R and Grimelius L: Colonic endocrine cells in inflammatory bowel disease. J Intern Med 242: 413-419, 1997.

2. El-Salhy M, Gundersen D, Hatlebakk JG and Hausken T: Chromogranin A cell density as a diagnostic marker for lymphocytic colitis. Dig Dis Sci 57: 3154-3159, 2012.

3. El-Salhy M, Gundersen D, Hatlebakk JG and Hausken T: High densities of serotonin and peptide YY cells in the colon of patients with lymphocytic colitis. World J Gastroenterol 18: 6070-6075, 2012.

4. El-Salhy M, Lomholt-Beck B and Gundersen TD: High chromogranin A cell density in the colon of patients with lymphocytic colitis. Mol Med Rep 4: 603-605, 2011.

5. Moran GW, Pennock J and McLaughlin JT: Enteroendocrine cells in terminal ileal Crohn's disease. J Crohn's Colitis 6: 871-880, 2012.

6. Moran GW, Leslie FC and McLaughlin JT: Crohn's disease affecting the small bowel is associated with reduced appetite and elevated levels of circulating gut peptides. Clin Nutr 32: 404-411, 2013.

7. Besterman HS, Mallinson CN, Modigliani R, Christofides ND, Pera A, Ponti V, Sarson DL and Bloom SR: Gut hormones in inflammatory bowel disease. Scand J Gastroenterol 18: 845-852, 1983.

8. El-Salhy M, Mazzawi T, Gundersen D, Hatlebakk JG and Hausken T: The role of peptide YY in gastrointestinal diseases and disorders (review). Int J Mol Med 31: 275-282, 2013. (Review).

9. Hirotani Y, Mikajiri K, Ikeda K, Myotoku M and Kurokawa N: Changes of the peptide YY levels in the intestinal tissue of rats with experimental colitis following oral administration of mesalazine and prednisolone. Yakugaku Zasshi 128: 1347-1353, 2008.

10. Vona-Davis LC and McFadden DW: NPY family of hormones: clinical relevance and potential use in gastrointestinal disease. Curr Top Med Chem 7: 1710-1720, 2007.

11. El-Salhy M, Suhr O and Danielsson A: Peptide YY in gastrointestinal disorders. Peptides 23: 397-402, 2002.

12. Tari A, Teshima H, Sumii K, Haruma K, Ohgoshi H, Yoshihara M, Kajiyama G and Miyachi Y: Peptide YY abnormalities in patients with ulcerative colitis. Jpn J Med 27: 49-55, 1988.

13. Sciola V, Massironi S, Conte D, Caprioli F, Ferrero S, Ciafardini C, Peracchi M, Bardella MT and Piodi L: Plasma chromogranin a in patients with inflammatory bowel disease. Inflamm Bowel Dis 15: 867-871, 2009.

14. Bishop AE, Pietroletti R, Taat CW, Brummelkamp WH and Polak JM: Increased populations of endocrine cells in Crohn's ileitis. Virchows Arch A Pathol Anat Histopathol 410: 391-396, 1987.

15. Manocha M and Khan WI: Serotonin and GI Disorders: an update on clinical and experimental studies. Clin Transl Gastroenterol 3: e13, 2012.

16. Stoyanova II and Gulubova MV: Mast cells and inflammatory mediators in chronic ulcerative colitis. Acta Histochem 104: 185-192, 2002.

17. Yamamoto H, Morise K, Kusugami K, Furusawa A, Konagaya T, Nishio Y, Kaneko H, Uchida K, Nagai H, Mitsuma T, et al: Abnormal neuropeptide concentration in rectal mucosa of patients with inflammatory bowel disease. J Gastroenterol 31: 525-532, 1996.

18. Payer J, Huorka M, Duris I, Mikulecky M, Kratochvílová H, Ondrejka P and Lukác L: Plasma somatostatin levels in ulcerative colitis. Hepatogastroenterology 41: 552-553, 1994.

19. Watanabe T, Kubota Y, Sawada T and Muto T: Distribution and quantification of somatostatin in inflammatory disease. Dis Colon Rectum 35: 488-494, 1992.

20. Koch TR, Carney JA, Morris VA and Go VL: Somatostatin in the idiopathic inflammatory bowel diseases. Dis Colon Rectum 31: 198-203, 1988.

21. Khan WI and Ghia JE: Gut hormones: emerging role in immune activation and inflammation. Clin Exp Immunol 161: 19-27, 2010.

22. Margolis KG and Gershon MD: Neuropeptides and inflammatory bowel disease. Curr Opin Gastroenterol 25: 503-511, 2009.

23. Ota E, Takeiri M, Tachibana M, Ishikawa Y, Umezawa K and Nishiyama S: Synthesis and biological evaluation of molecular probes based on the 9-methylstreptimidone derivative DTCM-glutarimide. Bioorg Med Chem Lett 22: 164-167, 2012. 
24. Shibasaki S, Yamashita K, Goto R, Wakayama K, Tsunetoshi Y, Zaitsu M, Igarashi R, Haga S, Ozaki M, Umezawa K and Todo S: Immunosuppressive effects of DTCM-G, a novel inhibitor of the mTOR downstream signaling pathway. Transplantation 95: 542-550, 2013.

25. Funakoshi T, Yamashita K, Ichikawa N, Fukai M, Suzuki T, Goto R, Oura T, Kobayashi N, Katsurada T, Ichihara S, et al: A novel NF- $\kappa \mathrm{B}$ inhibitor, dehydroxymethylepoxyquinomicin, ameliorates inflammatory colonic injury in mice. J Crohn's Colitis 6: 215-225, 2012.

26. El-SalhyM,Umezawa K,Gilja OH,HatlebakkJG,GundersenD and Hausken T: Amelioration of severe TNBS induced colitis by novel AP-1 and NF- $\kappa$ B inhibitors in rats. ScientificWorldJournal 2014 $1-8,2014$

27. Takeiri M, Tachibana M, Kaneda A, Ito A, Ishikawa $Y$ Nishiyama S, Goto R, Yamashita K, Shibasaki S, Hirokata G, et al: Inhibition of macrophage activation and suppression of graft rejection by DTCM-Glutarimide, a novel piperidine derived from the antibiotic 9-methylstreptimidone. Inflamm Res 60: 879-888, 2011.

28. Ishikawa Y, Tachibana M, Matsui C, Obata R, Umezawa K and Nishiyama S: Synthesis and biological evaluation on novel analogs of 9-methylstreptimidone, an inhibitor of NF-kappaB. Bioorg Med Chem Lett 19: 1726-1728, 2009.

29. Ueki S, Yamashita $K$, Aoyagi $T$, Haga $S$, Suzuki T, Itoh $T$, Taniguchi M, Shimamura T, Furukawa H, Ozaki M, et al: Control of allograft rejection by applying a novel nuclear factor-kappaB inhibitor, dehydroxymethylepoxyquinomicin. Transplantation 82 : $1720-1727,2006$

30. Matsumoto N, Ariga A, To-e S, Nakamura H, Agata N, Hirano S, Inoue $\mathrm{J}$ and Umezawa K: Synthesis of NF-kappaB activation inhibitors derived from epoxyquinomicin C. Bioorg Med Chem Lett 10: 865-869, 2000.

31. Umezawa $\mathrm{N}$, Matsumoto $\mathrm{N}$, Iwama $\mathrm{S}$, Kato $\mathrm{N}$ and Higuchi $\mathrm{T}$ : Facile synthesis of peptide-porphyrin conjugates: towards artificial catalase. Bioorg Med Chem 18: 6340-6350, 2010.

32. El-Salhy M, Gilja OH, Gundersen D, Hatlebakk JG and Hausken T: Endocrine cells in the ileum of patients with irritable bowel syndrome. World J Gastroenterol 20: 2383-2391, 2014.

33. El-Salhy M, Gundersen D, Hatlebakk JG and Hausken T: Low-Grade inflammation in the rectum of patients with sporadic irritable bowel syndrome. Mol Med Rep 7: 1081-1085, 2013.
34. Elson CO, Sartor RB, Tennyson GS and Riddell RH: Experimental models of inflammatory bowel disease. Gastroenterology 109: 1344-1367, 1995.

35. Low D, Nguyen DD and Mizoguchi E: Animal models of ulcerative colitis and their application in drug research. Drug Des Devel Ther 7: 1341-1357, 2013.

36. Spiller R: Serotonin and GI clinical disorders. Neuropharmacology 55: 1072-1080, 2008.

37. Egger M, Beer AG, Theurl M, Schgoer W, Hotter B, Tatarczyk T, Vasiljevic D, Frauscher S, Marksteiner J, Patsch JR, et al: Monocyte migration: a novel effect and signaling pathways of catestatin. Eur J Pharmacol 598: 104-111, 2008.

38. Feistritzer C, Mosheimer BA, Colleselli D, Wiedermann CJ and Kähler CM: Effects of the neuropeptide secretoneurin on natural killer cell migration and cytokine release. Regul Pept 126: 195-201, 2005

39. Ferrero E, Magni E, Curnis F, Villa A, Ferrero ME and Corti A: Regulation of endothelial cell shape and barrier function by chromogranin A. Ann N Y Acad Sci 971: 355-358, 2002.

40. Wang H, Steeds J, Motomura Y, Deng Y, Verma-Gandhu M, El-Sharkawy RT, McLaughlin JT, Grencis RK and Khan WI: $\mathrm{CD}^{+} \mathrm{T}$ cell-mediated immunological control of enterochromaffin cell hyperplasia and 5-hydroxytryptamine production in enteric infection. Gut 56: 949-957, 2007.

41. Cloëz-Tayarani I and Changeux JP: Nicotine and serotonin in immune regulation and inflammatory processes: a perspective. J Leukoc Biol 81: 599-606, 2007.

42. Stefulj J, Cicin-Sain L, Schauenstein K and Jernej B: Serotonin and immune response: effect of the amine on in vitro proliferation of rat lymphocytes. Neuroimmunomodulation 9: 103-108, 2001.

43. Betten A, Dahlgren C, Hermodsson S and Hellstrand K: Serotonin protects NK cells against oxidatively induced functional inhibition and apoptosis. J Leukoc Biol 70: 65-72, 2001.

44. Laberge S, Cruikshank WW, Beer DJ and Center DM: Secretion of IL-16 (lymphocyte chemoattractant factor) from serotonin-stimulated $\mathrm{CD}^{+} \mathrm{T}$ cells in vitro. J Immunol 156: 310-315, 1996.

45. Soga F, Katoh N, Inoue $\mathrm{T}$ and Kishimoto S: Serotonin activates human monocytes and prevents apoptosis. J Invest Dermatol 127: 1947-1955, 2007 